\title{
加速度センサを用いた運動体速度の時間領域測定
}

\author{
非会員 古山 和典* 非会員 野呂 光生* \\ 正員 平田 晃正 ${ }^{*}$ 正員藤原 修*
}

\section{Time Domain Measurement of Moving Object Speed Using Acceleration Sensor}

Kazunori Koyama*, Non-member, Mitsuo Noro*, Non-member, Akimasa Hirata*, Member,

Osamu Fujiwara*, Member

In this study, we proposed a time-domain measurement method of moving object speed with a commercially available acceleration sensor. The sensor of this kind is normally used to measure the acceleration of a stationary vibration object, while it is not applicable to the measurement of a transient moving object due to the frequency response of the sensor itself. An impulsive sensor response was derived from the free-drop movement of a metallic sphere. The deconvolution allows the sensor to measure the acceleration in the time domain, which was validated through the measurement of the speed of a hand-held metal piece approaching a target.

キーワード : 加速度センサ, 時間領域測定, 逆たたみこみ積分

Keywords : Acceleration sensor, time domain measurement, deconvolution

\section{1. まえがき}

半導体技術の著しい進歩に伴い, 電子機器の高速・多機 能化が進んだ半面, 高速・低電圧動作の集積回路に起因し て, 電磁雑音に対する機器イミュニティ（耐性）の劣化が 著しい。特に, 帯電人体からの静電気放電 (ESD : ElectroStatic Discharge）で生ずる過渡的電磁雑音はマイクロ波帯にわた る広帯域の周波数スペクトルを含み, 電子機器に深刻な電 磁障害を及ぼすとされる。筆者らの研究グループでは, 帯 電人体がもつ金属棒からの放電電流を測定し, 同特性が帯 電電圧との関係において金属棒の接近速度に大きく依存す ることを示したが(1), 速度測定までは至らなかった。本論文 では, 上述の実験で金属棒の放電対象への接近速度の定量 的把握を目的として，市販の加速度センサを用いた過渡的 な運動体速度の時間領域測定を示す。

\section{2. 加速度センサの原理と校正}

加速度センサの外形寸法と内部構造を図 1 に示す。加速 度センサは, 圧電素子に加わる力学的ストレス $F$ をそれに 比例する電荷量 $Q$ に変換するもので, 図に示すようにベー スに垂直に立てられたポストに円筒状のせん断型圧電素子 が装着され, 円筒外周にはおもり $m$ が取り付けられている。 加速度 $\alpha$ 圧電素子に加わると, そのストレス $F$ は, $F=m \alpha$ となるので, 加速度 $\alpha$ に比例した $Q$ が発生する。この $Q$ を 電圧信号として取り出せば，加速度が測定できる。一般に,
この種のセンサは，定常振動に対する加速度の測定に使用 されるので, 過渡的な運動物体に対してはセンサ自身の周 波数特性を考慮する必要がある。本論文では, 自由落下運 動に対するセンサの出力応答 $a_{m}(t)$ からセンサ系自身のイン パルス応答 $h(t)$ を導出し, 逆たたみこみ積分（デコンボリュ ーション）による過渡的な運動物体の速度の推定法を提案 する。図 2 は金属球を用いた落下運動の配置図を示す。図 $3(\mathrm{a})$ に測定電圧波形 $a_{m}(t)$ とデコンボリューション波形 $a(t)$ を, 図3(b)には速度波形 $s(t)$ をそれぞれ示す。ここで, 波形 $a(t)$ が重力加速度 $g\left(=9.8\left[\mathrm{~m} / \mathrm{s}^{2}\right]\right)$ となるように校正係数 $k\left[\mathrm{mV} / \mathrm{m} / \mathrm{s}^{2}\right]$ を求めると, $1.00552\left[\mathrm{mV} / \mathrm{m} / \mathrm{s}^{2}\right]$ となる。なおセン サ系のインパルス応答 $h(t)$ は, 測定電圧波形 $a_{m}(t)$ が $g \cdot u(t)$ $(u(t)$ : 単位階段関数 $)$ に対するインディシャル応答に対応 するので, $a_{m}(t)$ を,

$$
\frac{a_{m}(t)}{g}=A\left(e^{-\alpha t}-e^{-\beta t}\right)
$$

という指数関数に当てはめて, これを微分して求めた。こ のとき, 運動物体の加速度に対する測定電圧波形を $a_{m}(t)$ と すれば，速度波形 $s(t)$ は，

$s(t)=\frac{1}{k} \frac{1}{A} \frac{1}{\beta-\alpha}\left\{a_{m}(t)+(\alpha+\beta) \int_{0}^{t} \alpha_{m}\left(t^{\prime}\right) d t^{\prime}+\alpha \beta \int_{0}^{t}(t-\tau) \alpha_{m}(\tau) d \tau\right\}$

から計算できる。図 3(b)は上式の計算波形と理論波形とがよ く一致していることを示す。

\footnotetext{
* 名古屋工業大学大学院情報工学専攻

Graduate School of Engineering, Nagoya Institute of Technology

Gokiso-cho, Showa-ku, Nagoya-shi, Aichi-ken , 466-8555
} 


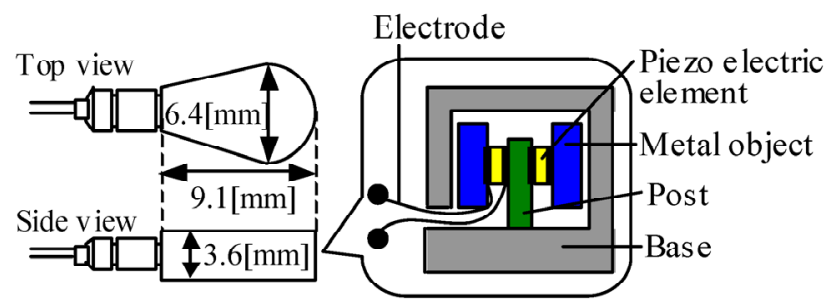

図 1 加速度センサの外観と内部構造

Fig. 1. General view and internal structure of acceleration sensor

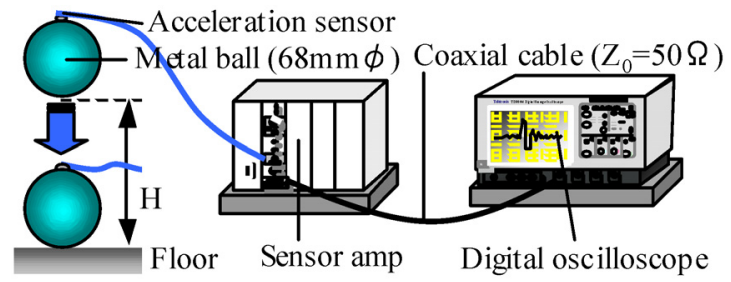

図 2 金属球の自由落下運動の実験測定系

Fig. 2. Measuring system of free-fall drop

(a)

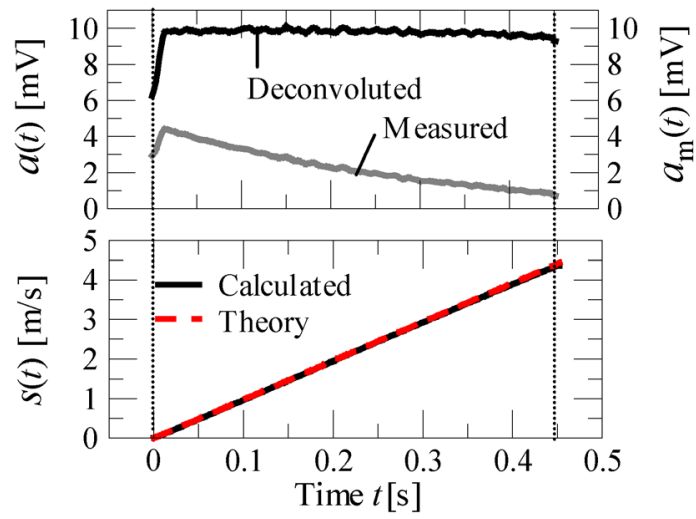

図 3 加速度センサの自由落下による校正

Fig. 3. Calibrated acceleration rate and velocity of metal sphere using proposed method

\section{3. 検証実験}

実験配置図を図 4 に示寸。図 5 に金属棒の接近速度の測 定例を示す。図 6(a)は計算で推定した速度波形の平均速度 $\bar{s}$ と測定配置から概算した平均速度 $\bar{s}_{m}\left(=H / T_{\mathrm{c}}\right)$ とを比較して 示す。図 6(b)は $\bar{s}$ と金属棒が衝突した瞬間の速度 $s_{c o l}$ との比 較を示す。ここで，加速度センサは手背上に発泡スチロー ルを介して固定し, 金属棒は SMA コネクタ中心電極に取り 付けた円板電極に距離 $H=10,20 \mathrm{~cm}$ 離れた位置から接近さ せたときの電圧を各 10 回測定し，速度波形を計算した。図 6(a)から，平均速度の比較はよく一致していることがわか る。また， $H=10 \mathrm{~cm}$ では衝突した瞬間の速度は平均速度の 概ね 2 倍近くあること, $H=20[\mathrm{~cm}]$ では 2 倍以下でばらつい ていること, などがわかる。後者は, 電極板が小さいため 慎重に衝突させようとした結果と考える。

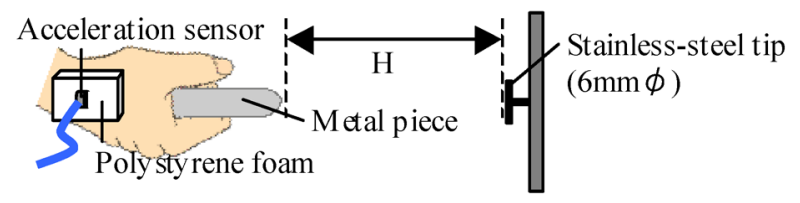

図 4 金属体接近運動の実験配置図

Fig. 4. Measuring system of approaching metal piece

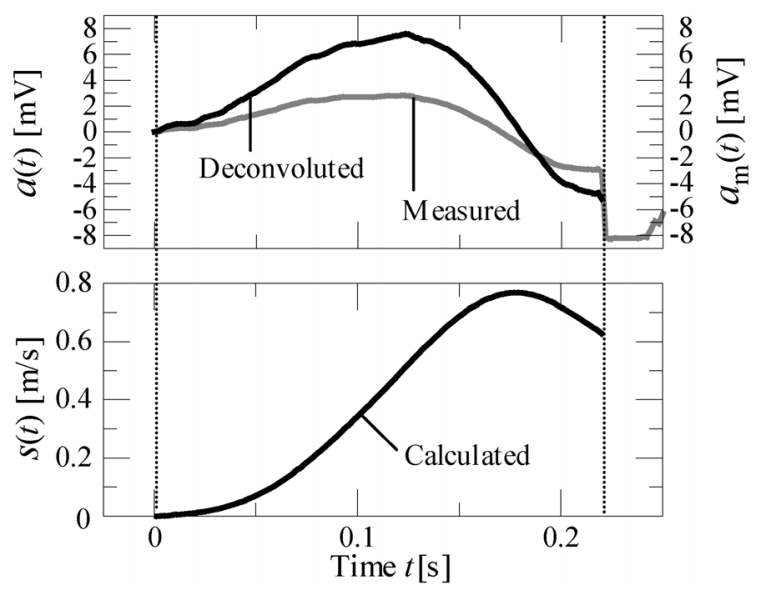

図 5 金属体接近速度の測定例

Fig. 5. Measurement example of measurement approaching speed of metal piece

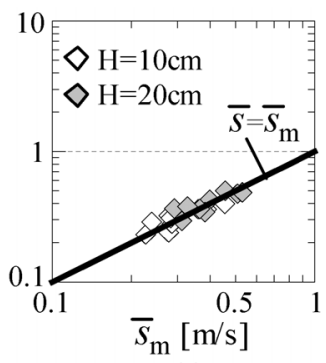

(a)

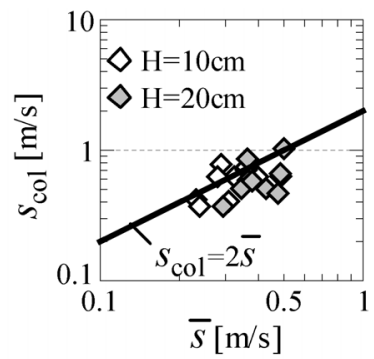

(b)
図 6 平均速度と衝突速度の評価

Fig. 6. Evaluation method of (a) average and (b) collision speeds

\section{4. むすび}

市販の加速度センサによる運動物体の時間領域測定法を 提案し，手にもった金属棒の接近速度を測定することで提 案法の妥当性を示した。今後の課題として, 帯電人体がも つ金属棒の接近速度と放電特性との定量関係を明らかにす ることがあげられる。

(平成 18 年 3 月 14 日受付)

\section{文献}

(1) Y. Taka, I. Mori, and O. Fujiwara : "Characteristic measurement for air discharge through hand-held metal piece from charged human-body", IEICE Technical Report, EMCJ2005-40, pp.109-114 (2005-06) (in Japanese)

高 義礼・森 育子・藤原 修:「帯電人体のもつ金属棒を介した気 中放電の特性測定」, 信学技報, EMCJ2005-40, pp.109-114 (2005-06) 